\title{
Effect of sub-zero temperatures and cement type on viability of Bacillus pseudofirmus in biological self-healing concrete
}

Jankutè, Augusta ${ }^{1,2}$, Guobužaitè, Simona ${ }^{1,2}$, Jakubovskis, Ronaldas², Gribniak, Viktor ${ }^{2}$, Urbonavičius, Jaunius ${ }^{1}$

${ }^{1}$ Department of Chemistry and Bioengineering, Vilnius Gediminas Technical University, Vilnius, Lithuania

${ }^{2}$ Laboratory of Innovative Building Structures, Vilnius Gediminas Technical University, Vilnius, Lithuania

Microbiologically induced calcite precipitation (MICP) can be used to fill cracks arising in concrete. Alkaliphilic spore-forming bacteria, which can survive extreme $\mathrm{pH}$ values and harsh conditions in concrete matrix, are needed for this purpose. In this study, the viability of Bacillus pseudofirmus in sub-zero temperatures and in a concrete matrix containing several types of cement with different $\mathrm{pH}$ and metal ion concentrations was investigated. Expanded clay (EC) was used as a carrier for two-component self-healing agent consisting of Bacillus pseudofirmus spores and calcium lactate. The concrete consists of EC, cement, sand and water. Viability of endospores was measured using a standard microbiological dilution-toextinction method by CFU counting after plating on alkaline nutrient agar. The results showed that after 72 days of incubation at temperatures below $0{ }^{\circ} \mathrm{C}\left(-20^{\circ} \mathrm{C}\right)$, the number of viable spores remained almost constant ( $\sim 10^{7} \mathrm{CFU} / \mathrm{g}$ of EC) compared to control specimens stored at the room temperature. That indicates that $B$. pseudofirmus has a potential to be used in biological self-healing concrete for the Northern Europe region with high number of freezethaw cycles. Out of four cement types commonly used in Lithuania, the best survival rate was obtained in a concrete mix using the low alkali white CEM I cement. The number of viable spores after three days of concrete curing varied from $2.34 \times 10^{3}$ to $6.59 \times 10^{4} \mathrm{CFU} / \mathrm{g}$ of EC. Thus, an additional coating of EC aggregates is needed to improve the viability of bacteria in the concrete. 